
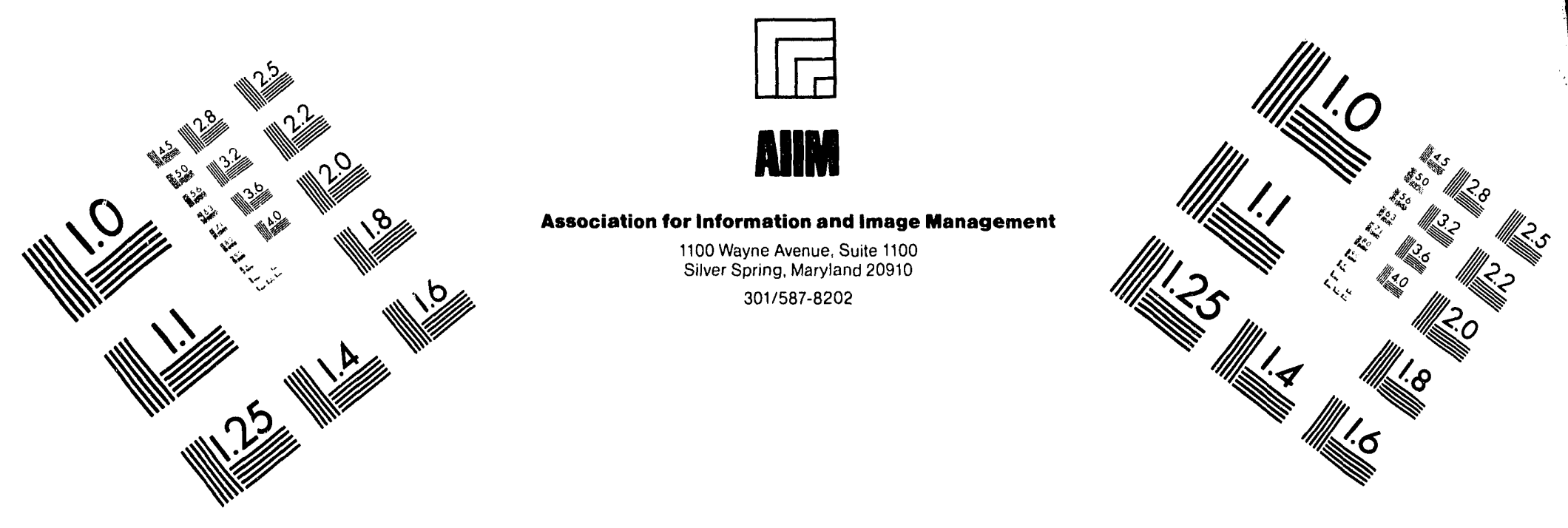

\title{
Centimeter
}

$\begin{array}{llllllllllllllll}1 & 2 & 3 & 4 & 5 & 6 & 7 & 8 & 9 & 10 & 11 & 12 & 13 & 14 & 15 & \mathrm{~mm}\end{array}$

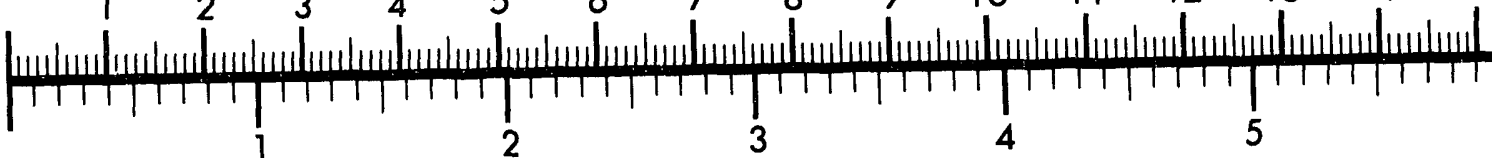

Inches
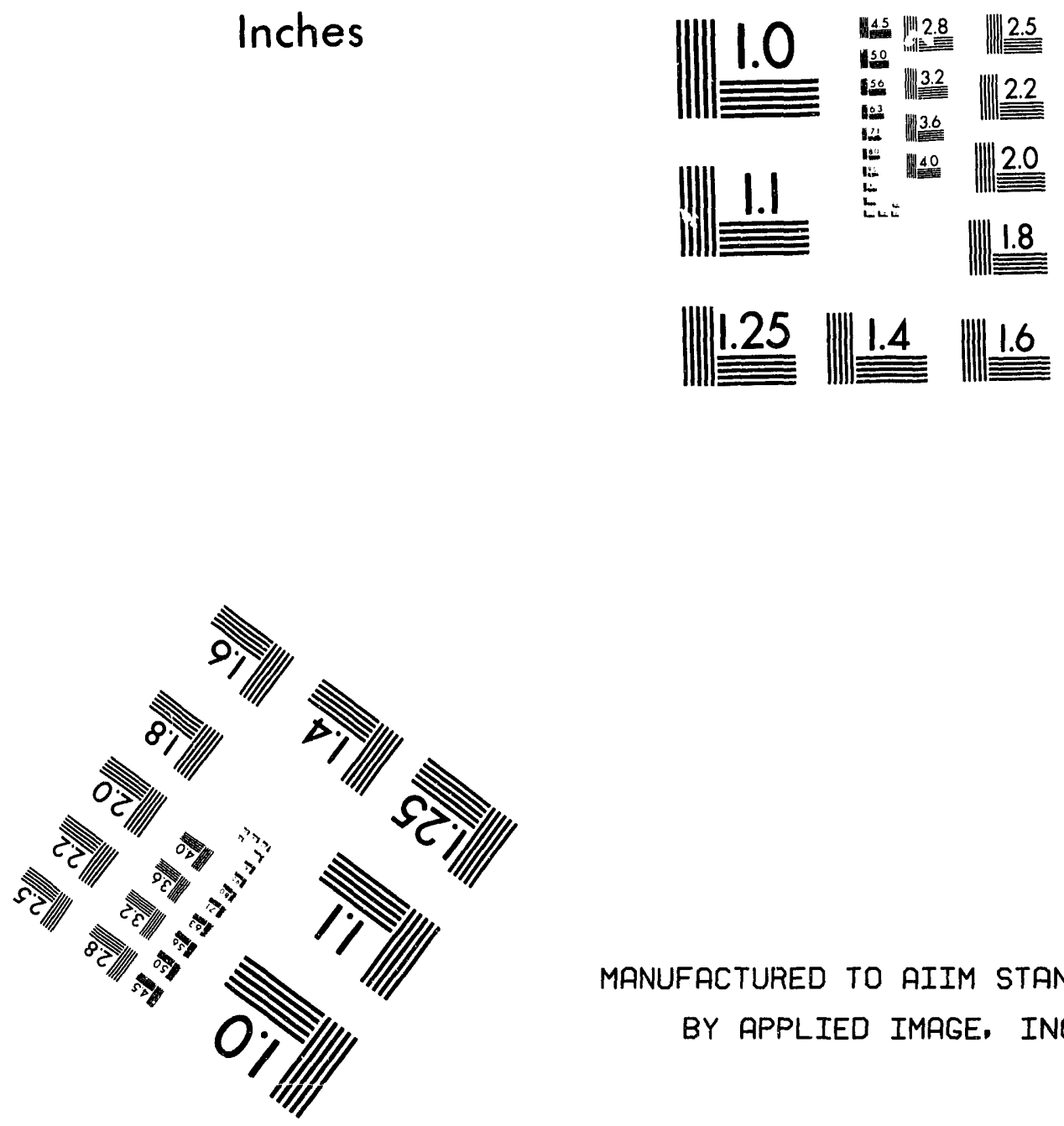

MANUFACTURED TO AIIM STANDARDS

BY APPLIED IMAGE, INC.

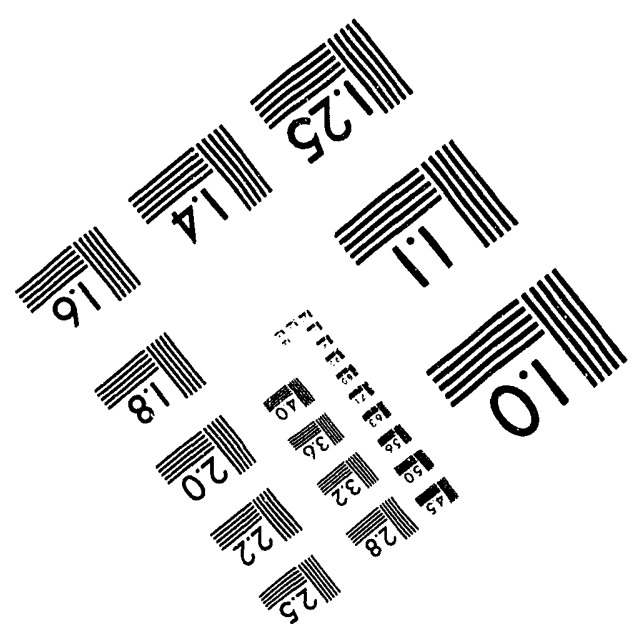



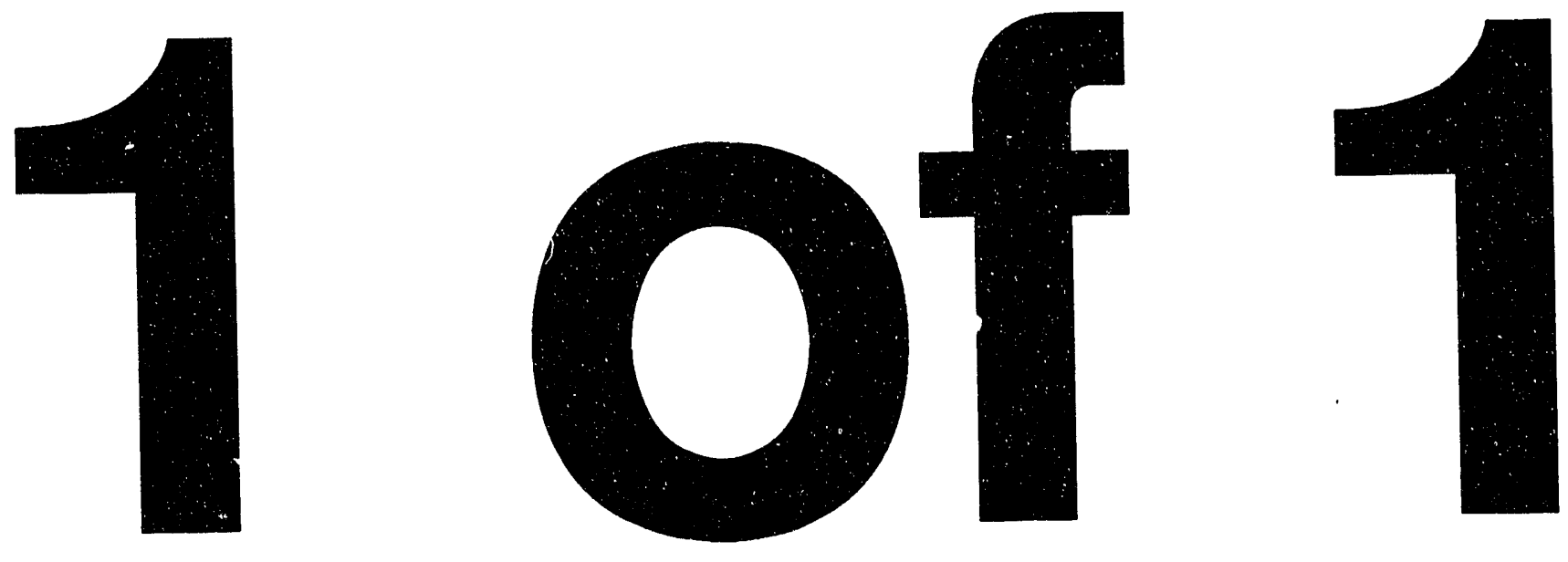

$=$ 


\section{Conf- $9305166-2$}

DOE/METC/C-93/7068

Upgrading of Raw Natural Gas Using High-Performance Polyner Membranes

Authors:

Stern, S.A. (Syracuse University)

Meyer, H.S. (Gas Research Institute)

Venkataraman, V.K. (DOE/METC)

Shoemaker, H.D. (DOE/METC)

Conference Title:

1993 American Filtration Society/North American

Membrane Society Meeting

Conference Location:

Rosemont, Illinois

Conference Dates:

May 3-6, 1993

Conference Sponsor:

American Filtration Society/North American Membrane Society

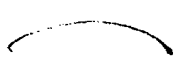

\section{DISCLAIMER}

This report was prepared as an account of work sponsored by an agency of the United States Government. Neither the United States Government nor any agency thereof, nor any of their employees, makes any warranty, express or implied, or assumes any legal liability or responsibility for the accuracy, completeness, or usefulness of any information, apparatus, product, or process disclosed, or represents that its use would not infringe privately owned rights. Reference herein to any specific commercial product, process, or service by trade name, trademark, manufacturer, or otherwise does not necessarily constitute or imply its endorsement, recommendation, or favoring by the United States Government or any agency thereof. The views and opinions of authors expressed herein do not necessarily state or reflect those of the United States Government or any agency thereof. 


\section{RECEIVED \\ JUN 011993 \\ OSTI}

\section{DISCLAIMER}

This report was prepared as an account of work sponsored by an agency of the United States Government. Neither the United States Govermment nor any agency therenf, nor any of their employees makes any warranty, express or implied, or assumes any legal liability or responsibility for the accuracy, completeness or usefulness of any information, apparatus, product, or process disclosed, or represents that its use would not infringe privately owned rights. Reference herein to any specific commercial product, process, or service by trade name, trademark, manufacturer, or otherwise, does not necessarily constitute or imply its endorsement, recommendation, or favoring by the United States Government or any agency thereof. The views and opinions of authors expressed herein do not necessarily state or reflect those of the United States Government or any agency thereof.

This report has been reproduced directly from the best available copy.

Available to DOE and DOE contractors from the Office of Scientific and Technical Information, P.O. Box 62, Oak Ridge, TN 37831; prices available froin (615)576-8401, FTS 626-8401.

Available to the public from the National Technical Information Service, U.S. Department of Commerce, 5285 Port Royal Rd., Springfield, VA 22161. 


\title{
Upgrading of Raw Natural Gas Using High-Performance Polymer Membranes
}

\author{
S. A. Stern, Syracuse University \\ Syracuse, New York \\ H. S. Meyer, Gas Research Institute \\ Chicago, Illinois \\ V. K. Venkataraman and H. D. Shoemaker, \\ U. S. Department of Energy, \\ Morgantown Energy Technology Center \\ Morgantown, West Virginia
}

\begin{abstract}
The separation of $\mathrm{CO}_{2}$ and $\mathrm{H}_{2} \mathrm{~S}$ from raw natural gas is essential for enhancing the heating value of the gas and for providing environmental safety during transportation and use. Membrane separation processes are particularly useful for this application because they are inherently energyefficient. Membrane processes also offer other important advantages, such as ease of scale-up due to module design, good space and weight efficiency and great flexibility in handling variations in the flow rate, pressure and composition of the raw natural gas streams. In a coordinated effort, the Gas Research Institute and the Department of Energy, Morgantown Energy Technology Center are funding an extensive study at Syracuse University on the relationships between the chemical structure of various polymers and their permeability to different gases. Based on criteria derived from this study, novel fluorine-containing polyimides that exhibit very high $\mathrm{CO}_{2} / \mathrm{CH}_{4}$ selectivities as well as significant $\mathrm{H}_{2} \mathrm{~S} / \mathrm{CH}_{4}$ selectivities were synthesized. These "dense" (homogeneous) membranes separated various mixtures of $\mathrm{CO}_{2} / \mathrm{CH}_{4}$ and $\mathrm{H}_{2} \mathrm{~S} / \mathrm{CH}_{4} / \mathrm{CO}_{2}$ at $35^{\circ} \mathrm{C}\left(95^{\circ} \mathrm{F}\right)$ and at pressures up to $10 \mathrm{~atm}$ ( $147 \mathrm{psi}$ ). The results of these measurements agree well with computer simulations. The $\mathrm{CO}_{2}$ content of $\mathrm{CH}_{4} / \mathrm{CO}_{2}$ mixtures containing as much as 40 mole percent $\mathrm{CO}_{2}$ can be reduced with the polyimide membranes to pipeline specifications $\left(\leq 2\right.$ mole percent $\mathrm{CO}_{2}$ ). To reduce the $\mathrm{H}_{2} \mathrm{~S}$ content of $\mathrm{H}_{2} \mathrm{~S} / \mathrm{CH}_{4} / \mathrm{CO}_{2}$ mixtures to pipeline specifications $\left(\leq 4 \mathrm{ppm} \mathrm{H}_{2} \mathrm{~S}\right.$ ), the membranes are best combined with conventional gas-absorption processes, such as a selective amine. Such "hybrid" processes for the upgrading of natural gas can be more economical than conventional gas-absorption processes alone.
\end{abstract}

Natural gas is a mixture of hydrocarbon and non-hydrocarbon gases. The well head composition of these gases varies greatly across the United States. To ensure that the natural gas consumer receives a consistent, safe product, most of the gas undergoes some degree of processing to meet "pipeline" specifications. This requires the removal of the following components from the light hydrocarbon fraction:

- carbon dioxide $\left(\mathrm{CO}_{2}\right)$, which is corrosive if wet and reduces the heating value;

- hydrogen sulfide $\left(\mathrm{H}_{2} \mathrm{~S}\right)$, which is corrosive and toxic;

- nitrogen $\left(\mathrm{N}_{2}\right)$, which is inert and reduces the heating value; 
- natural gas liquids (NGL), which are valuable by-products that can cause operational problems if they condense in the pipeline;

- water $\left(\mathrm{H}_{2} \mathrm{O}\right)$, which forms hydrates and promotes corrosion; and

- other trace constituents that may be limited by contracts or good engineering practices (including oxygen $\left(\mathrm{O}_{2}\right)$, helium $(\mathrm{He})$, oils and grease, other sulfur species).

The objective of the research programs is to evaluate the potential usefulness of membrane separation processes for the removal of acid gases $\left(\mathrm{CO}_{2}\right.$ and $\left.\mathrm{H}_{2} \mathrm{~S}\right)$ from low-quality natural gas. The maximum pipeline specifications for $\mathrm{CO}_{2}$ and $\mathrm{H}_{2} \mathrm{~S}$ are typically 2 mole-percent and $4 \mathrm{ppm}$ (volume), respectively. Across the U.S., 28.2 trillion cubic feet (Tcf) (or 20\%) of the currently producing raw reserves contain greater than $2 \% \mathrm{CO}_{2}$, while, in the future, $185 \mathrm{Tcf}$ (or $83 \%$ ) of the new discoveries are expected to exceed the $\mathrm{CO}_{2}$ specification. Similarly, $19 \mathrm{Tcf}$ of currently producing reserves and $77 \mathrm{Tcf}$ of new discoveries are expected to exceed the $\mathrm{H}_{2} \mathrm{~S}$ specification.

Commercially, there are four general types of processes used to removed these acid gases from natural gas, namely:

- reversible chemical or physical absorption into a liquid solvent;

- direct conversion through absorption and oxidation in a liquid;

- adsorption on a solid; and

- physical separation through a permeable membrane.

The primary means used commercially is the chemical solvent. In those systems, an amine solution is circulated between an absorption and regeneration tower. In the absorber, the amine flows counter-current to the flow of the high pressure, raw gas. The acid gases chemically react with the basic solution. The solution, now rich in acid gases, is pumped to a low pressure, high temperature regenerator to reverse the absorption reaction. The lean amine is cooled and returned to the absorber. The acid gas stream is treated further as required to handle the $\mathrm{CO}_{2}$ and/or $\mathrm{H}_{2} \mathrm{~S}$ streams.

Membrane separation units offer several process advantages that make them attractive for acid gas removal from natural gas. Within the basic unit itself, there are no moving parts, membrane units can be easily replaced, variations in flow rates can be easily accommodated and startup can be accomplished in a very short time. In addition, the available information suggests that the operation of a membrane process may require less labor than other process options. However, current membrane performance and fabrication technology may limit the use of this technology to relatively small-scale applications because of the modularity of the separation units. Other separations technologies, because of favorable economies of scale, will be more attractive at larger scale. The crossover between membranes and amines is dependent on the concentration of $\mathrm{CO}_{2}$ and $\mathrm{H}_{2} \mathrm{O}$ content of the gas, as well as site specific issues, but in a study conducted for the Gas Research Institute (GRI), M.W. Kellogg found that the crossover may be about 30-75 million standard cubic feet per day $(\mathrm{MMscf} / \mathrm{d})$ with the current generation of membranes. 
GRI and the Department of Energy, Morgantown Energy Technology Center (DOE-METC) have initiated programs to develop new membranes for natural gas separations that offer the potential to reduce processing costs and expand the arena of applicability to larger-scale operations. New types of polymer membranes that exhibit high gas selectivities are being tested for this purpose by Syracuse University. This project is comprised of gas permeability and separation measurements, process design studies and economic evaluations.

A laboratory-scale apparatus of the "time-lag" type was constructed for this project. The apparatus is being used for both (1) gas permeability and selectivity measurements and (2) gas separation measurements. The first types of measurements are being made at very low "stage cuts" $(<0.001)$ to determine the permeability coefficients of the components of $\mathrm{CH}_{4} / \mathrm{CO}_{2}$ and $\mathrm{CH}_{4} / \mathrm{CO}_{2} / \mathrm{H}_{2} \mathrm{~S}$ mixtures, as well as the $\mathrm{CO}_{2} / \mathrm{CH}_{4}$ and $\mathrm{H}_{2} \mathrm{~S} / \mathrm{CH}_{4}$ selectivities of the membranes. (The stage cut is the fraction of the feed permeating through a membrane.) Values of the permeability coefficients are required for computer simulations of membrane processes for the removal of $\mathrm{CO}_{2}$ and $\mathrm{H}_{2} \mathrm{~S}$ from low-quality natural gas. The gas separation measurements are being made at higher stage cuts to validate the results of the computer simulations.

Four new types of polymers synthesized at Syracuse University were evaluated for possible use as membrane materials for the upgrading of low-quality natural gas. Three of these polymers, D-2, E-1 and F-1, were polyimides; the fourth polymer, G-1, was a polypyrrolone. The D-2 and G-1 polymers contain fluorine atoms in their repeat units, whereas E-1 and F-1 do not. The permeability measurements were made at $95^{\circ} \mathrm{F}\left(35^{\circ} \mathrm{C}\right)$ with binary $\mathrm{CH}_{4} / \mathrm{CO}_{2}$ gas mixtures containing $10,20,30$, and 40 mole-percent $\mathrm{CO}_{2}$, and with a ternary gas mixture of 87.5 molepercent $\mathrm{CH}_{4}, 9.7$ mole-percent $\mathrm{CO}_{2}$, and 2.8 mole-percent $\mathrm{H}_{2} \mathrm{~S}$. The feed ("upstream") pressure was varied in the range from about 59 to 200 psia (4 to $13.6 \mathrm{~atm}$ ), whereas the permeate ("downstream") pressure was 0.005 to 0.58 psia ( 0.3 to 30 torr). The polymers were used in the form of "dense" (homogeneous) membranes.

The $\mathrm{CO}_{2} / \mathrm{CH}_{4}$ selectivity of the polymers studied, at $95^{\circ} \mathrm{F}\left(35^{\circ} \mathrm{C}\right)$ and at $147 \mathrm{psia}(10 \mathrm{~atm})$, was found to decrease in the following polymer crder when measured with a binary $\mathrm{CH}_{4} / \mathrm{CO}_{2}$ gas mixture:

$\mathrm{CO}_{2} / \mathrm{CH}_{4}$ Selectivity Order

\begin{tabular}{|l|l|l|l|l||}
\hline Polymer & D-2 $>$ & F-1 $>$ & G-1 $>$ & E-1 \\
\hline Feed Gas @ 10\% CO 2 & 85 & 52 & 45 & 39 \\
\hline Feed Gas @ 40\% CO 2 & 60 & 40 & 35 & 26 \\
\hline
\end{tabular}

The $\mathrm{CO}_{2} / \mathrm{CH}_{4}$ selectivity decreases with increasing $\mathrm{CO}_{2}$ concentration in the feed mixture, suggesting that the polymers were plasticized (swelled) by $\mathrm{CO}_{2}$, as has been reported for many

\section{Presented at 1993 American Filtration Society/North American Membrane Society Meeting} Rosemont, IL Paper C2.3 
other glassy polymers, as shown in Figure 1 for polymer D-2. The decrease in the $\mathrm{CO}_{2} / \mathrm{CH}_{4}$ selectivity with increasing $\mathrm{CO}_{2}$ concentration was due mainly to an increase in the $\mathrm{CH}_{4}$ permeability; by contrast, the $\mathrm{CO}_{2}$ permeability remained essentially unchanged. This behavior is because $\mathrm{CO}_{2}$ exhibits a much higher solubility in the polymers than $\mathrm{CH}_{4}$. Consequently, $\mathrm{CO}_{2}$ plasticizes the polymers to a much greater extent than $\mathrm{CH}_{4}$, and thereby increases their permeability to $\mathrm{CH}_{4}$.

As typically shown in Figure 1 for polymer D-2, the $\mathrm{CO}_{2} / \mathrm{CH}_{4}$ selectivities of the D-2, G-1 and F-1 polymers are not significantly affected by an increase in the total "upstream" pressure in the range from 59 to 200 psia. The effect of upstream pressure on polymer E-1 has not yet been studied.

The $\mathrm{CO}_{2}$ permeability of the polymers, at $95^{\circ} \mathrm{F}$ $\left(35^{\circ} \mathrm{C}\right), 147$ psia $(10 \mathrm{~atm})$ when measured with a binary gas mixture containing 10 mole-percent $\mathrm{CO}_{2}$, decreased in the following polymer order:

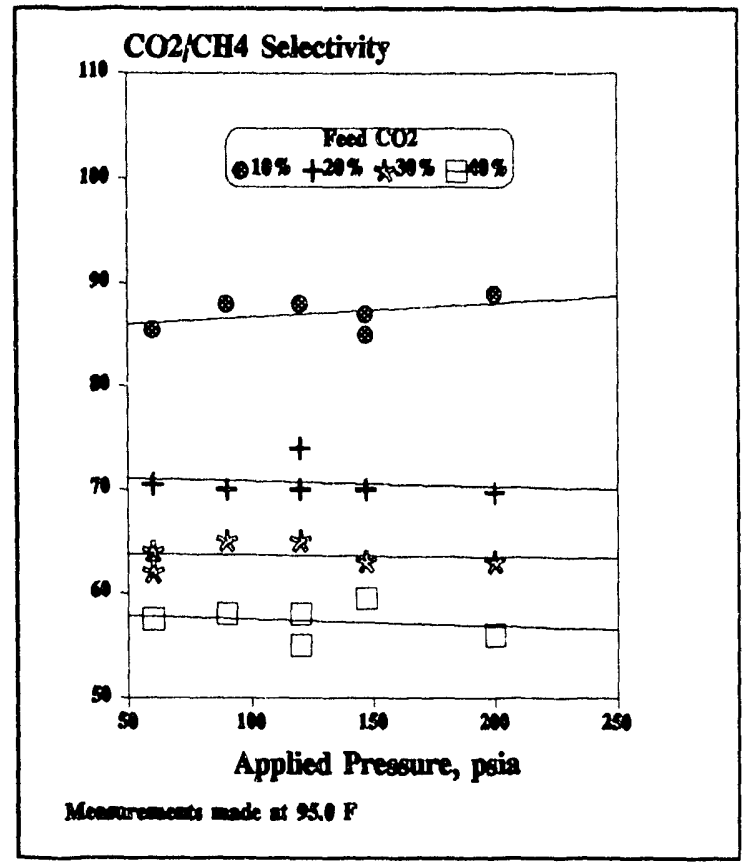

Figure 1. $\mathrm{CO}_{2} / \mathrm{CH}_{4}$ Selectivity of Polyimide $\mathrm{D-2}$ is fairly constant with total applied pressure.

\begin{tabular}{|l|c|c|c|c|}
\hline Polymer & G-1 $>$ & D-2 $>$ & F-1 $\approx$ & E-1 \\
\hline $\mathrm{CO}_{2}$ Permeability $\times 10^{10}$ & 29.2 & 7.25 & 1.96 & 1.65 \\
\hline
\end{tabular}

where the permeability coefficient for $\mathrm{CO}_{2}$ is given in units of $\mathrm{cm}^{3}(\mathrm{STP}) \cdot \mathrm{cm} / \mathrm{s} \cdot \mathrm{cm}^{2} \cdot \mathrm{cm} \cdot \mathrm{cmHg}$. It is seen that the $\mathrm{CO}_{2}$ permeability does not decrease in inverse polymer order with increasing $\mathrm{CO}_{2} / \mathrm{CH}_{4}$ selectivity.

The extent of separation achieved with D-2 polyimide membranes was measured as a function of the stage cut, as shown in Figure 2. The measurements were made at $95^{\circ} \mathrm{F}\left(35^{\circ} \mathrm{C}\right)$ at 147 psia (10 atm) using two feed mixtures: a $90 / 10$ mixture of $\mathrm{CH}_{4} / \mathrm{CO}_{2}$ and a ternary $87.5 / 9.7 / 2.8$ mixture of $\mathrm{CH}_{4} / \mathrm{CO}_{2} / \mathrm{H}_{2} \mathrm{~S}$. The $\mathrm{CO}_{2} / \mathrm{CH}_{4}$ and $\mathrm{H}_{2} \mathrm{~S} / \mathrm{CH}_{4}$ selectivities determined with the ternary mixture were 94 and 16, respectively. The retentate and permeate compositions determined experimentally agreed well with the values predicted from computer simulations assuming perfect-mixing conditions in the permeability cell. The computer simulations made use of the permeability coefficients obtained from separation measurements at very low stage cuts.

\section{Presented at 1993 American Filtration Society/North American Membrane Society Meeting Rosemont, $\mathbf{L}$ Paper C2.3}


Cellulose acetate (CA) is used as a membrane material for the upgrading of raw natural gas on an industrial scale. All four new polymers evaluated have higher $\mathrm{CO}_{2} / \mathrm{CH}_{4}$ selectivities

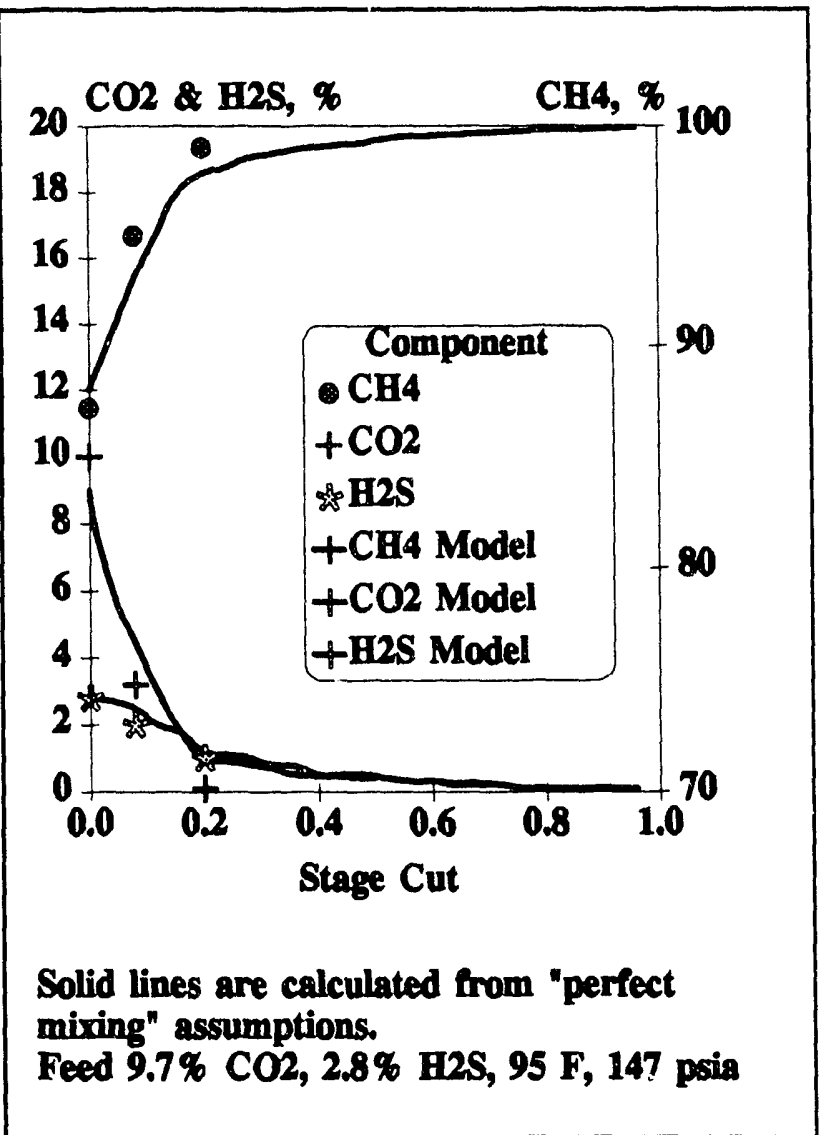

Figure 2. $\mathrm{CH}_{4}, \mathrm{CO}_{2}$ and $\mathrm{H}_{2} \mathrm{~S}$ in the retentate matched well with predictions. than $\mathrm{CA}$. The D-2 polyimide has a $\mathrm{CO}_{2} / \mathrm{CH}_{4}$ selectivity that is nearly 2.5 times higher than that of CA under comparable conditions. The D-2 and G-1 polymers also exhibit higher permeabilities to $\mathrm{CO}_{2}$ than $\mathrm{CA}$, the permeability coefficient for $\mathrm{CO}_{2}$ of $\mathrm{G}-1$ being nearly ten times higher than that of $\mathrm{CA}$.

Polyimide D-2 and the polypyrrolone G-1 clearly surpass $\mathrm{CA}$ in both $\mathrm{CO}_{2} / \mathrm{CH}_{4}$ selectivity and in $\mathrm{CO}_{2}$ permeability. The E-1 and $\mathrm{F}-1$ polyimides exhibit higher $\mathrm{CO}_{2} / \mathrm{CH}_{4}$ selectivity, but their $\mathrm{CO}_{2}$ permeabilities are $35-45 \%$ lower than that obtained with $\mathrm{CA}$. However, higher $\mathrm{CO}_{2} / \mathrm{CH}_{4}$ selectivities are more important than higher intrinsic permeabilities (as characterized by gas permeability coefficients) because high permeation rates can be achieved by decreasing the effective thickness of membranes, that is, by using the membranes in asymmetric or composite forms. Process simulations and economic evaluations that are currently in progress will provide a more quantitative comparison between the performances of the new membranes and $C A$.

Acknowledgement: Support from the Gas Research Institute, under Contract Number 5086-2601441, and from the Department of Energy/Morgantown Energy Technology Center, under Grant Number DE-AC21-91MC28072, for this work is gratefully acknowledged. 

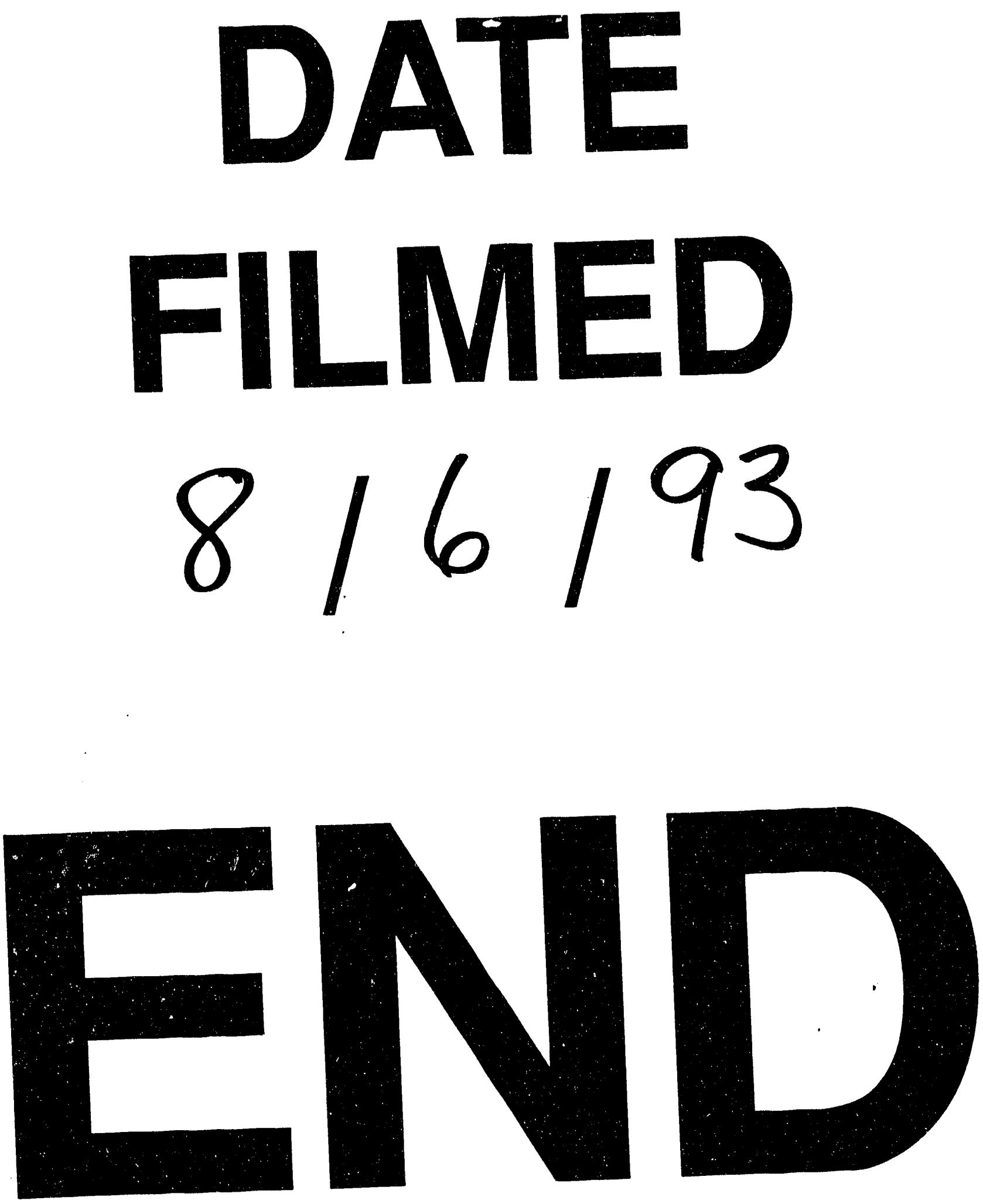


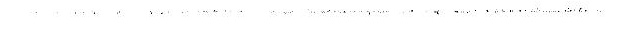

